\title{
Development of the banana plants 'Prata Anã' and 'FHIA-01' under the effect of paclobutrazol applied on the soil
}

\author{
EMANUEl MAIA ${ }^{1}$, DALMO L. SiQUeira ${ }^{1}$, LUIZ C.C. SALOMÃo ${ }^{1}$, LUIZ A. PETERNelli ${ }^{2}$, \\ MARÍLIA C. VENTRELLA ${ }^{3}$ and RITHIELY P.Q. CAVATTE ${ }^{3}$ \\ ${ }^{1}$ Departamento de Fitotecnia, Setor de Fruticultura, Universidade Federal de Viçosa (UFV) \\ Av. P.H. Rolfs s/n, Centro, 36570-000 Viçosa, MG, Brasil \\ ${ }^{2}$ Departamento de Informática, Setor de Estatística, UFV, Av. P.H. Rolfs s/n, Centro, 36570-000 Viçosa, MG, Brasil \\ ${ }^{3}$ Departamento de Biologia Vegetal, UFV, Av. P.H. Rolfs s/n, Centro, 36570-000 Viçosa, MG, Brasil
}

Manuscript received on April 3, 2008; accepted for publication on September 9, 2008; presented by ELIBIO L. RECH

\begin{abstract}
Under some cultivation conditions, excessive growth of the pseudostem of banana plants can be considered a limiting factor, and thus, the use of growth regulators can constitute a valid alternative. This work aimed to evaluate the action of paclobutrazol on the growth of the pseudostem of banana plants and other characteristics of their development. An experiment was installed with five paclobutrazol doses $\left(0 ; 0.5 ; 1.0 ; 1.5\right.$; and $2.0 \mathrm{~g}$ of a.i. plant $\left.{ }^{-1}\right)$ combined $^{-1}$ with two banana plant cultivars ('Prata Anã' and 'FHIA-01'). Paclobutrazol did not affect the number of days from planting to flowering, total leaf area and leaf emission rate. However, it increased leaf permanence on the plants and sucker number, reduced the foliar area of the leaves emitted after its application and provided an average reduction in pseudostem height of $26 \%$.
\end{abstract}

Key words: foliar area, growth analysis, growth regulator, Musa spp., suckers.

\section{INTRODUCTION}

Brazilian banana plant cultivation has undergone changes in the past years mainly related to seedling production due to two strong reasons: the advance of pest and disease into free areas and the formation of large export-oriented orchards. This scenario led to the production of a large amount of seedlings with high phytosanitary standard within a short period of time, made possible by the use of micro-propagation techniques (Leonel et al. 2004). For these seedlings to be produced, the matrix plants must be healthy and maintained under conditions that minimize the possibility of con-

Correspondence to: Emanuel Maia

Present address: Departamento de Agronomia, Universidade Federal de Rondônia (UNIR), Av. Norte-Sul 7300, Nova Morada, 78987-000 Rolim de Moura, RO, Brasil.

E-mail: emanuelfms@gmail.com tamination, what prompted some propagation laboratories to opt for maintaining their matrices under protected environment.

A common problem of banana plants cultivated under protected environment is the excessive growth of their pseudostem, which can reach more than six meters for some cultivars, requiring more planting spacing and causing, in some cases, the rupture of the plastic film surrounding the roof (El Otmani et al. 1992, Gubbuk et al. 2004). Thus, the use of growth regulators to reduce plant height may be a solution for plants cultivated under protected environment, as shown by some promising studies on banana plant growth regulation (El Otmani et al. 1992, Jeyakumar et al. 2003). Among the main growth regulators used in agriculture the most prominent is paclobutrazol (Khurshid et al. 1997, Yim et al. 1997, Bandara et al. 1998, Rademacher 2000, 
Mouco and Albuquerque 2005). The main plant responses observed after paclobutrazol application are: smaller length of the new shoots, green color intensification, increased chlorophyll concentration and reduced foliar area (Khurshid et al. 1997, Yim et al. 1997, Carvalho et al. 2005, Mouco and Albuquerque 2005). 'Grande Naine' banana plants showed reduced pseudostem and foliar area growth, increased chlorophyll concentration and no change in cycle duration and plant productivity during the first production cycle (El Otmani et al. 1992). Thus, this work proposes to evaluate the effects of paclobutrazol on some development characteristics of the banana plants 'Prata Anã' and 'FHIA-01' during the first production cycle.

\section{MATERIALS AND METHODS}

The experiment was conducted in the Fruit Culture Sector of the Universidade Federal de Viçosa (UFV), Viçosa, MG. The municipality of Viçosa is located in Zona da Mata Mineira $\left(20^{\circ} 45^{\prime} 20^{\prime \prime} \mathrm{S}\right.$ and $\left.42^{\circ} 52^{\prime} 40^{\prime \prime} \mathrm{W}\right)$, at 651 meters of altitude in relation to the sea level. The experiment was conducted from August 2005 to December 2006. The treatments used were five paclobutrazol doses $\left(0 ; 0.5 ; 1.0 ; 1.5\right.$; and 2.0 g of a.i. plant $\left.{ }^{-1}\right)$ combined with two banana plant cultivars ('Prata Anã' and 'FHIA-01'). Cv. Prata Anã (AAB) was selected because it ranks among the cultivars with the largest planted area, and are well accepted in the domestic market (Leonel et al. 2004), besides belonging to the type 'Prata', which accounts for approximately $60 \%$ of the area cultivated in Brazil (Silva et al. 2002). The tetraploid cv. FHIA01 (AAAB) was selected for presenting characteristics similar to those of cv. Prata Anã and for being resistant to Black Sigatoka (Mycosphaerella fijiensis) and other important diseases, such as Panama disorder (Fusarium oxysporum f.sp. cubense) (Alves 1999). The seedlings used for the implantation of the experiment came from the Cell and Plant Tissue Culture Laboratory of the Department of Plant Sciences of the UFV.

The experiment was installed in the field on November 3, 2005 in a factorial scheme and a complete randomized block design (Steel et al. 1997) with eight repetitions and one plant as experimental unit in $2.5 \times 2.5 \mathrm{~m}$ spacing. Due to height heterogeneity at the moment of planting, the seedlings were grouped into similar height classes. Paclobutrazol (Pachlobutrazol 100 CE, 10\% i.a., Wiser) was applied when the plants reached an average height of $75 \mathrm{~cm}$ considering the distance between soil and the second leaf of the foliar rosette on March 6, 2006. The product was applied on the soil surface, with humidity close to field capacity, around the pseudostem at a mean distance of $25 \mathrm{~cm}$. The plants received water complementation during the most severe hydric deficit periods in the region. The cultural practices followed the current recommendations (Alves 1999).

Periodic evaluations consisted of: pseudostem height $(\mathrm{cm})$, measurement from the soil up to second leaf of the foliar rosette; pseudostem circumference $(\mathrm{cm})$, measurement at $0.30 \mathrm{~m}$ height from the soil surface; number of totally expanded leaves in the plant at the moment of evaluation; leaf emission rate and foliar area, using the non-destructive method (Turner 2003). These evaluations occurred between 11/13/2005 and 09/28/2006. Every three months after paclobutrazol application, thinning (sucker removal) and dead leaf removal were performed, followed by sucker number and fresh mass evaluation. Mean sucker fresh mass per plant and total number of suckers produced by the plants during the period evaluated were considered as experimental unit. Other complementary evaluations were plant height measurement $(\mathrm{cm})$, from soil surface to rachis insertion point and number of days from planting to rachis emission, with the latter being evaluated during inflorescence emission.

To carry out the analysis of variance, two decompositions of the variation sources were used. For the data submitted to periodical collection, the split plot in time was applied with a factorial scheme being used to install the experiment in the plots. For the remaining variables, variation decomposition was usually applied for factorial scheme (Steel et al. 1997). When necessary, regression models were applied to study the variables. The following criteria were taken into consideration for selecting the models: lower AIC (Akaike information criterion) value, model significance and greater determination coefficient $\left(\mathrm{R}^{2}\right)$.

To describe plant growth along the months, the logistic model

$$
Y_{i}=\frac{a}{\left(1+e^{b-k \times t_{i}}\right)}
$$


was used where:

$$
\begin{aligned}
Y_{i}= & \text { represents the growth observed in time } t_{i} \\
t_{i}= & \text { the time spent from transplanting until deter- } \\
& \text { mination of pseudostem height, in months; } \\
a= & \text { asymptotic height; } \\
b= & \text { scale parameter; } \\
k= & \text { mean growth rate. }
\end{aligned}
$$

All analyses were carried out with the help of the statistical software R (R Core Team 2006).

\section{RESULTS AND DISCUSSION}

No significant effect was observed for the "dose $\times$ cultivar" interaction for any of the characteristics evaluated (Table I). The cultivar 'Prata Anã' presented higher leaf number, leaf emission rate and sucker number, shorter pseudostem height, foliar area of the leaves emitted after PBZ application and lower sucker fresh mass than the cultivar FHIA-01. Paclobutrazol (PBZ) did not influence pseudostem circumference and number of days from planting to flowering, in agreement with the results obtained by El Otmani et al. (1992), who evaluated the effect of PBZ on the banana plants 'Grande Naine' cultivated in protected environment in Morocco. On the other hand, in cloves (Dianthus caryophyllus L.) increase in the number of days from planting to flowering was verified only in the plants that received doses above $0.9 \mathrm{mg}$ of a.i. of PBZ plant ${ }^{-1}$ (Bañón et al. 2002).

Pseudostem growth reduction could be observed 17 days after application of the product, with a mean reduction of $14 \%$ (Fig. 1a). Increased PBZ doses led to shorter pseudostem height at the end of the assessment period (Fig. 1b). The parameters estimated confirm that increased PBZ doses provided a reduction in pseudostem height $(a)$ and growth mean rate $(k)$, Table II. Percent difference in pseudostem height at the end of the assessment period, between the control dose and the other doses varied between 18 and 30\%, with an approximate mean of $26 \%$. Doses between 1.5 and $2.0 \mathrm{~g}$ of a.i. of PBZ plant ${ }^{-1}$ provided similar effects on the growth mean rate and the final pseudostem height. PBZ was found to provide an exponential reduction in plant height (Fig. 1c) at the end of the assessment period, indicating a strong reduction in the endogenous levels of gibberellins, responsible for pseudostem elongation (Fernández et al. 1995, Winkler and Helentjaris 1995).

Since a relation was visually observed between pseudostem height at the moment of application and the PBZ effect on plant growth, this situation was more carefully evaluated. Figure 1d presents mean height of the plants in the blocs before application and at the end of the assessment period (after product application). Block 1 plants were found to present shorter pseudostem height before application and at the end of the evaluation period while block 8 plants showed, on an average, the highest height. A regression analysis among pseudostem heights at the moment of PBZ application in function of added pseudostem height after product application presented a positive and significant regression coefficient ( $p=0.0011)$. This result indicates that PBZ inhibiting effect was lower when the plants had a higher height at the moment of application, what could have been explained by an effect of dilution in the total mass of the plant or by some problem associated to the sites of action of the product (less activity and/or less sensitivity). The results found agree with those obtained by (Bandara et al. 1998), who, evaluating the effect of time of PBZ application on vase-cultivated potatoes, observed that the effect of PBZ applied at the initial stages was higher than when applied at advanced culture stages.

No differences were observed in total foliar area of the PBZ-treated plants (Table I). These results disagree with those found by El Otmani et al. (1992) who observed a reduction in the total foliar area of the banana plants 'Grande Naine' after application of $1.0 \mathrm{~g}$ of a.i. of PBZ plant ${ }^{-1}$. However, a reduction in the foliar area was verified in the leaves emitted after PBZ application, as measured by the foliar area of the totally expanded youngest leaf. This observation showed that additions in the PBZ doses reduced the foliar area per leaf (Fig. 1e). A likely explanation for this fact (smaller leaves without affecting the total foliar area) would be a tendency in increased leaf permanence on PBZ-treated plants (Table III), since the product did not cause leaf emission rate differences (Table I). These results are supported by those found by Yim et al. (1997) in rice with PBZ application, increasing the number of leaves per seedling, reducing the dimension of the leaves formed 

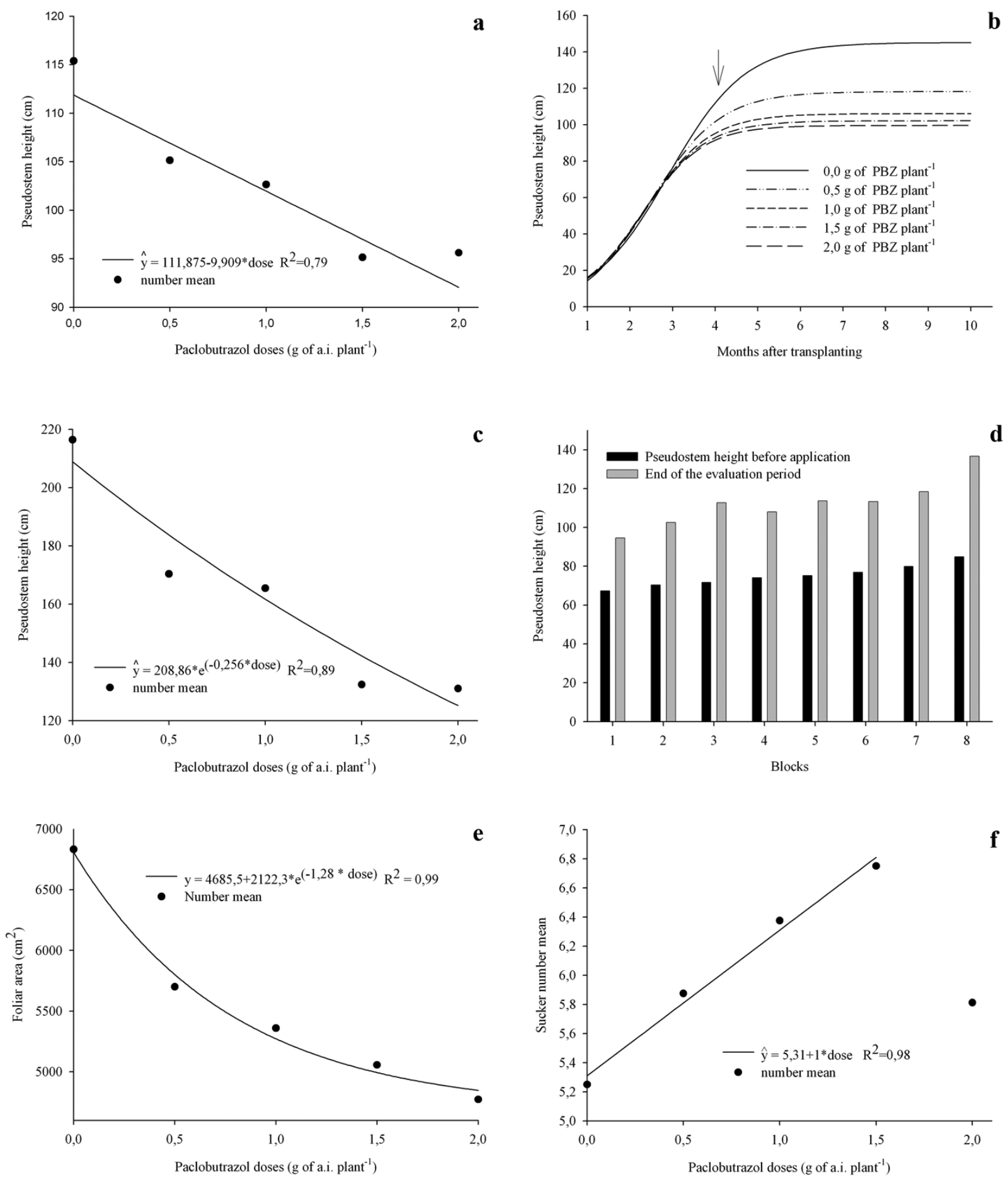

Fig. 1 
TABLE I

F test probability values of the analysis of variance (p), coefficient of variation (CV\%) and mean per cultivar for the variables: pseudostem circumference (PSC), number of days from planting to flowering (NDF), pseudostem height (PSH), plant height (HEI), total foliar area (TFA), foliar area of the totally expanded youngest leaf (YLA), leaf number (LN), leaf emission rate (LER), sucker number (SN), sucker fresh mass (SFM).

\begin{tabular}{|c|c|c|c|c|c|c|}
\hline \multirow[b]{2}{*}{ Variables } & \multicolumn{3}{|c|}{$\mathrm{p}$} & \multirow[b]{2}{*}{$\mathrm{CV}(\%)$} & \multicolumn{2}{|c|}{ Means $^{(1)}$} \\
\hline & Cultivars & Dose & $\begin{array}{c}\text { Dose } \times \\
\text { cultivar interaction }\end{array}$ & & Prata Anã & FHIA 01 \\
\hline $\mathrm{PSC}(\mathrm{cm})$ & 0.409 & 0.475 & 0.728 & 7.66 & $64.18 \mathrm{a}$ & $63.32 \mathrm{a}$ \\
\hline $\mathrm{NDF}$ & 0.939 & 0.090 & 0.452 & 9.58 & $354.48 \mathrm{a}$ & $342.44 \mathrm{a}$ \\
\hline PSH (cm) & 0.006 & $<0.001$ & 0.300 & 13.27 & $74.39 \mathrm{~b}$ & $79.80 \mathrm{a}$ \\
\hline HEI (cm) & 0.014 & $<0.001$ & 0.915 & 12.97 & $157.67 \mathrm{~b}$ & $169.91 \mathrm{a}$ \\
\hline TFA $\left(\mathrm{cm}^{2}\right)$ & 0.920 & 0.180 & 0.980 & 21.70 & $39792.00 \mathrm{a}$ & $39918.00 \mathrm{a}$ \\
\hline YLA $\left(\mathrm{cm}^{2}\right)$ & 0.001 & $<0.001$ & 0.380 & 18.13 & $5119.00 \mathrm{~b}$ & $5969.00 \mathrm{a}$ \\
\hline $\mathrm{LN}$ & $<0.001$ & 0.002 & 0.877 & 11.65 & $12.23 \mathrm{a}$ & $10.58 \mathrm{~b}$ \\
\hline LER (month leaves ${ }^{-1}$ ) & $<0.001$ & 0.265 & 0.558 & 15.19 & $1.80 \mathrm{a}$ & $1.54 \mathrm{~b}$ \\
\hline SN & 0.013 & 0.016 & 0.935 & 20.96 & $6.38 \mathrm{a}$ & $5.65 \mathrm{~b}$ \\
\hline SFM $(\mathrm{kg})$ & 0.032 & 0.205 & 0.602 & 41.70 & $10.35 \mathrm{~b}$ & $12.70 \mathrm{a}$ \\
\hline
\end{tabular}

(1) Mean pairs followed by same letter, in the lines, do not differ by the $\mathrm{F}$ test at $5 \%$ de probability.

TABLE II

Parameters estimated for the growth curves, $Y_{i}=a /\left(1+e^{b-k \times t_{i}}\right)$, and coefficient of determination $\left(R^{2}\right)$ to describe the growth of banana plants 'Prata Anã' and 'FHIA 01' under five doses of paclobutrazol (PBZ, g of a.i. plant ${ }^{-1}$ ) applied on soil.

\begin{tabular}{c|c|c|c|c}
\hline PBZ doses & \multicolumn{3}{|c|}{ Growth curve parameters } & \multirow{2}{*}{$\mathrm{R}^{2}$} \\
& $a$ & $b$ & $k$ & \\
\hline 0.0 & 145.53 & 3.14 & 1.08 & 0.996 \\
\hline 0.5 & 118.79 & 2.96 & 1.19 & 0.993 \\
\hline 1.0 & 106.51 & 2.88 & 1.24 & 0.989 \\
\hline 1.5 & 102.61 & 2.91 & 1.29 & 0.988 \\
\hline 2.0 & 99.96 & 2.98 & 1.33 & 0.984 \\
\hline
\end{tabular}

TABLE III

Means of the number of leaves of banana plants 'Prata Anã' and 'FHIA 01' in function of paclobutrazol doses (PBZ), along the experiment evaluation.

\begin{tabular}{c|c|c|c|c|c|c}
\hline \multirow{2}{*}{ Months } & \multicolumn{5}{|c|}{ PBZ doses (g of a.i. plant ${ }^{-1}$ ) } & \multirow{2}{*}{$\hat{\mathrm{C}}$} \\
\cline { 2 - 6 } & 0.0 & 0.5 & 1.0 & 1.5 & 2.0 & \\
\hline \multicolumn{7}{c}{ Number of leaves } \\
\hline March & 14.44 & 14.69 & 14.25 & 14.38 & 13.89 & $-0.56^{\mathrm{ns}}$ \\
\hline June & 9.37 & 10.19 & 11.94 & 11.25 & 12.50 & $8.37^{*}$ \\
\hline September & 10.31 & 10.25 & 12.31 & 12.06 & 12.07 & $5.43^{+}$ \\
\hline
\end{tabular}

$\hat{\mathrm{C}}$ : contrast among doses $0.0 \mathrm{~g}$ of a.i. of PBZ (control) and the other levels of PBZ. Levels of significance of the contrast by the Scheffé test: ns $=$ non significant; ${ }^{*}=5 \%$ of probability; $+=10 \%$ of probability. 
after PBZ application, but without any alterations in the total foliar area of the plant.

PBZ did not influence sucker fresh mass, indicating that the plants, regardless of the paclobutrazol dose applied, had a similar sucker production and that the occurrences of sucker number variations were due to the appearance of a larger number of lateral buds (Table I). Since it was not possible to adjust a model that could explain the result found for all the doses evaluated for sucker number, we opted for adjusting a simple linear regression model up to the dose of $1.5 \mathrm{~g}$ of a.i. plant ${ }^{-1}$, considering that at the dose of 2.0 of a.i. plant $^{-1}$ there was an expressive sucker emission reduction (Fig. 1f). (Hamid and Williams 1997) studying the behavior of Swainsona formosa under the effect of different growth regulators, verified that $\mathrm{PBZ}$ application was followed by an increase in the number of lateral shoots, that would be reduced at higher PBZ levels.

\section{RESUMO}

Em algumas condições de cultivo o crescimento excessivo do pseudocaule de bananeiras pode ser considerado um fator limitante, assim a utilização de reguladores de crescimento pode constituir uma alternativa. O presente trabalho teve por objetivo avaliar a ação do paclobutrazol sobre o crescimento do pseudocaule de bananeiras e outras características do seu desenvolvimento. Para isso foi instalado um experimento com cinco doses do paclobutrazol $(0 ; 0,5 ; 1,0 ; 1,5 ;$ e $2,0 \mathrm{~g}$ de i.a. planta $^{-1}$ ) combinadas com dois cultivares de bananeira ('Prata Anã' e 'FHIA-01'). O paclobutrazol não afetou o número de dias do plantio ao florescimento, a área foliar total e a taxa de emissão de folhas. Contudo, aumentou a permanência das folhas nas plantas e o número de perfilhos, reduziu a área foliar das folhas emitidas após a sua aplicação e proporcionou uma redução média de $26 \%$ na altura do pseudocaule.

Palavras-chave: área foliar, análise de crescimento, reguladores de crescimento, Musa spp., perfilhos.

\section{REFERENCES}

Alves EJ. 1999. A cultura da banana: aspectos técnicos, socioeconômicos e agroindustriais. 2. Ed. Brasília: Embrapa - SPI/Cruz das Almas, Embrapa CNPMF, 585 p.

BANDARA MS, TANino KK AND WATERER DR. 1998. Effect of pot size and timing of plant growth regulator treat- ments on growth and tuber yield in greenhouse-grown Norland and Russet Burbank potatoes. J Plant Growth Regul 17: 75-59.

BAÑón S, GonzÁlez A, CANo EA, Franco JA AND FERNÁNDEZ JA. 2002. Growth, development and colour response of potted Dianthus caryophyllus cv. Mondriaan to paclobutrazol treatment. Sci Hortic 94: 371-377.

Carvalho JABs, Peixoto CP, Silva So, Ledo CAS, PEIXoto MFSP AND Alves JS. 2005. Uso da giberelina $\mathrm{GA}_{3}$ na seleção do porte de bananeira das cultivares Prata e Prata-Anã. Rev Bras Frutic 27: 449-453.

El Otmani M, Jabri K And Sedki M. 1992. Paclobutrazol effect on development of greenhouse-growth banana: 2year assessments. Acta Hort 296: 89-96.

Fernández JAS, Doumas P, Teisson C And Côte F. 1995. Identificación y cuantificación de giberalinas en plantas variantes somaclónales y normales de Musa (cv. 'Grande Naine' AAA) mediante HPLC y espectrometria de masa. Proceeding $11^{\text {th }}$ Reunión de la Associación para la Cooperación en Investigación de Banano en El Caribe y en América Tropical, 13-18 February, San José, Costa Rica. Available at $<$ http://musalit.inibap.org/byindex_ result.php?lang $=$ en\&index $=$ nomed\&idselect $=152$ \&page $=12>$.

Gubbuk H, Pekmezc IM And ERkan M. 2004. Production potential of Cavendish cultivars ( $M u s a$ spp. AAA) under greenhouse and field conditions in subtropical areas of Turkey. Acta Agric Scand 54: 249-253.

HAMID MM AND WILliams RR. 1997. Effect of different types and concentrations of plant growth retardants on Sturt's desert pea (Swainsona formosa). Sci Hortic 71: 79-85.

Jeyakumar P, Kumar N And Kavino M. 2003. Physiological response of banana cv. 'Robusta' (AAA) to foliar applied plant growth regulators on productivity. Madras Agric J 90: 702-706.

Khurshid T, Mcneil DL, Trought MCT And Hill GD. 1997. The response of young 'Braeburn' and 'Oregon spur delicious' apple trees growing under an ultrahigh density planting system to soil-applied paclobutrazol: I. Effect on reproductive and vegetative growth. Sci Hortic 71: 11-24.

Leonel S, Gomes EM And Pedroso CJ. 2004. Desempenho agronômico de bananeiras micropropagadas em Botucatu - SP. Rev Bras Frutic 26: 245-248.

Mouco MAC And Albuquerque JAS. 2005. Efeito do paclobutrazol em duas épocas de produção da mangueira. Bragantia 64: 219-225. 
R Development Core Team. 2006. R: A language and environment for statistical computing. R Foundation for Statistical Computing, Vienna, Austria.

RADEMACHER W. 2000. Growth retardants: effects on gibberellin biosynthesis and other metabolic pathways. Annu Rev Plant Physiol Plant Mol Biol 51: 01-531.

Silva SO, Flores JCO AND Lima Neto FP. 2002. Avaliação de cultivares e híbridos de bananeira em quatro ciclos de produção. Pesq Agropec Bras 37: 1567-1574.

Steel GD, Torrie JH AND Dickey DA. 1997. Principles and procedures of statistics: a biometrical approach. $3^{\text {rd }}$ ed., New York: McGraw-Hill, 666 p.
TURNER DW. 2003. An integral method for estimating total leaf area in bananas. Infomusa 12: 15-17.

Winkler RG And HelentJaris T. 1995. The maize Dwarf3 gene encodes a cytochrome $\mathrm{P}_{450}$-mediated early step in gibberellin biosynthesis. Plant Cell 7: 1307-1317.

Yim KO, KWON YW AND BAYER DE. 1997. Growth responses and allocation of assimilates of rice seedlings by paclobutrazol and gibberellin treatment. J Plant Growth Regul 16: 35-41. 